\title{
Comparing Three DNA Extraction Procedures for Cost, Efficiency, and DNA Yield
}

\author{
D.W. Lickfeldt ${ }^{1}$, N.E. Hofmann, J.D. Jones, A.M. Hamblin, and \\ T.B. Voigt \\ Department of Natural Resources and Environmental Sciences, University of \\ Illinois, Urbana, IL 61801
}

Additional index words. RAPD, PCR, fingerprinting, Poa pratensis

\begin{abstract}
An efficient deoxyribonucleic acid (DNA) extraction procedure that yields large quantities of DNA would provide adequate DNA for a large number of different analytical procedures. This study was conducted to compare three DNA extraction procedures for cost, time efficiency, and DNA content while extracting DNA from Kentucky bluegrass (Poa pratensis L.). Three students at the Univ. of Illinois with varying levels of DNA extraction experience conducted DNA extractions using Plant DNeasy ${ }^{\mathrm{TM}}$ Mini Kits, Plant DNAzol ${ }^{\circledR}$ Reagent, and a PEX/CTAB buffer. Costs varied significantly with cost (US\$) per DNA sample of $\$ 3.04$ for the DNeasy ${ }^{\mathrm{TM}}$ method, $\$ 0.99$ for the DNAzol ${ }^{\circledR}$ method, and $\$ 0.39$ for the PEX/CTAB extraction. The DNAzol ${ }^{\circledR}$ method was the fastest; although extracting $2.8 \mathrm{ng}$ less DNA than the DNeasy ${ }^{\mathrm{TM}}$ method, it did not require the use of hazardous organic solvents, and random amplified polymorphic DNA (RAPD) markers were satisfactory for DNA fingerprinting of Kentucky bluegrass cultivars. The PEX/CTAB method, which did not include a tissue homogenization step, did not have reproducible banding patterns due to miniscule and inconsistent quantities of DNA extracted, or possibly due to inadequate purification. The investigator with the least DNA extraction experience was the slowest, while extracting $\mathbf{7 5 \%}$ more DNA. All three methods are easily adapted to laboratories having personnel with different levels of experience. The DNAzol ${ }^{\circledR}$ Reagent method should save time and money, with reproducible results when many individual plant samples need to be identified. Chemical names used: potassium ethyl xanthogenate (PEX); cetyltrimethyl ammonium bromide (CTAB)
\end{abstract}

The number of plant samples needed to characterize the population of a plant community can be quite large (Krebs, 1989) and, if a relatively expensive tool such as DNA markers is used to identify individual plants (Golembiewski et al., 1997; Sweeney and Danneberger, 1995; Weising et al., 1995), the resources required can be great. A recent study determined that 379 plant samples are required to estimate the varietal composition of a blended Kentucky bluegrass (Poa pratensis L.) stand to within \pm 5 percentage points of the true mean (Lickfeldt, 2001). Future ecological studies may utilize repeated sampling over time. This requires a large number of samples to identify factors that

Received for publication 23 Apr. 2001. Accepted for publication 15 Oct. 2001. This paper is a portion of a thesis submitted by D.W. Lickfeldt in fulfillment of a $\mathrm{PhD}$ at the Univ. of Illinois-Urbana. We thank T. Rocheford, B. Branham, and T. Fermanian for professional guidance, and the Illinois Turfgrass Foundation for financial assistance. Mention of products and equipment is for identification purposes only and does not imply a warranty or endorsement to the exclusion of other products that may be similar.

${ }^{1}$ To whom reprint requests should be addressed. Current address: Field Development Biologist, Dow AgroSciences L.L.C., 9330 Zionsville Rd., Indianapolis, IN 46268. E-mail address: DWLickfeldt@ dow.com

${ }^{2}$ Dept. of Natural Resources and Environmental Sciences, Univ. of Illinois, Urbana, IL 61801. contribute to the composition of turfgrass stands. A plant DNA extraction procedure that is inexpensive, time efficient, and yields large quantities of DNA would allow for the characterization of a turfgrass stand by DNA fingerprinting. Furthermore, quantifying differences between laboratory investigators may help identify those workers most suited for this type of research.

There are several acceptable methods of extracting DNA from plants. Many researchers utilize a cetyltrimethyl ammonium bromide (CTAB) buffer (Doyle and Doyle, 1990; Rogers and Bendich, 1994; Weir et al., 1996) and organic solvents such as phenol and chloroform (Strózycki and Legocki, 1995) for DNA extraction from plants. Plant DNeasy ${ }^{\mathrm{TM}}$ Mini Kits (Qiagen, Valencia, Calif.) have also grown in popularity because they extract total genomic DNA without phenol or chloroform. The kit's spin column combines the binding properties of silica-gel chromatography with microspin centrifuge technology to yield large quantities of DNA. Alternatively, Plant DNAzol ${ }^{\circledR}$ Reagent [GIBCO BRL, Grand Island, N.Y. (formerly Life Technologies)] is an isolation buffer that is a guanidine-detergent lysing reagent. The reagent allows for the selective precipitation of genomic DNA while hydrolyzing RNA (Lin and Kuo, 1998).

Tissue homogenization by grinding in liquid $\mathrm{N}$ can be the most time-consuming step in a DNA-extraction procedure. When liquid
$\mathrm{N}$ grinding is required, the quantity of DNA extracted from different samples can vary; such variability can detract from DNA amplification reproducibility (Weising et al., 1995). Therefore, Williams and Ronald (1994) used an isolation buffer containing potassium ethyl xanthogenate (PEX) and CTAB to extract and purify plant DNA without tissue homogenization. Several laboratories have developed unique procedures to expedite DNA extraction using microwaves (Saini et al., 1999), a reciprocal shaker with ceramic beads (Geuna et al., 2000), or crushing leaf tissue on a paper matrix (Lin et al., 2000).

When extracting DNA, the reproducibility and quality of the results can not be sacrificed in the interest of expediting procedures. For instance, false negative polymorphic bands can occur in polymerase chain reaction (PCR)-based research as a result of contamination by DNA-binding substances such as polysaccharides, deactivation of enzymes such as nucleases, or physical methods that can cause shearing of DNA. The contaminants can diminish the detection of polymorphisms between different individuals (Gelfard and White, 1990; Weising et al., 1995). Therefore, a successful isolation procedure should avoid contamination and damage to the DNA while extracting a large percentage of the genomic DNA present.

Existing DNA extraction and purification procedures vary in cost efficiency and reproducibility. An ideal procedure should have a limited number of steps to reduce experimental error, a limited use of hazardous solvents, a reduced need for specialized equipment, and a method that is affordable. Based on these concerns, the objectives of this study were to compare three DNA extraction procedures and three laboratory investigators for cost, time efficiency, and DNA content following extraction of Kentucky bluegrass DNA.

\section{Materials and Methods}

A bulk sample of leaf and sheath tissue was collected on 12 Sept. 2000 from 22-week-old, greenhouse-grown, 'Blacksburg' Kentucky bluegrass. The turf was maintained in a greenhouse with daily watering, 14-h days with supplemental light $\left(200 \mu \mathrm{mol} \cdot \mathrm{s}^{-1} \cdot \mathrm{m}^{-2}\right)$, and the temperature maintained at $20 \pm 2{ }^{\circ} \mathrm{C}$. One hundred milligram (fresh weight) samples of leaf and sheath tissue were collected using scissors, harvesting all plant tissue just above the crown and thatch (verdure). The top $5.4 \mathrm{~cm}$ of leaf and sheath tissue was stored at $-80^{\circ} \mathrm{C}$.

The three DNA extraction methods used and procedures for the generation of RAPD were described by Lickfeldt (2001). The three extraction methods evaluated were DNeasy ${ }^{\mathrm{T}}$ Plant Mini Kits with tissue homogenization (Qiagen), Plant DNAzol ${ }^{\circledR}$ Reagent with tissue homogenization (Lin and Kuo, 1998), and PEX/CTAB buffer without tissue homogenization (Williams and Ronald, 1994). The costs of materials for each method were collected from current product catalogs (Dec. 2000). The equipment costs were not quanti- 
fied, but all extraction methods required the use of a microcentrifuge, vortex, and, with the exception of the DNAzol ${ }^{\circledR}$ method, a heated water bath.

Three investigators were chosen from a laboratory at the Univ. of Illinois-Urbana/ Champaign to evaluate the three DNA methods. Two investigators were graduate students (\#1 and \#3), and Investigator \#2 was an undergraduate student with 2 years of laboratory experience. Investigator \#1 had 2 years of laboratory experience, while \#3 had no prior experience with DNA marker methods. To become familiar with the extraction methods, each investigator practiced each DNA extraction method on five plant samples prior to initiation of the study.

The experiment was a two-factor factorial arrangement in a randomized complete-block design blocked by replication. DNA isolation was conducted over three consecutive weeks (24 Sept.-14 Oct. 2000), with each week equal (Block) to one replication. The study was blocked over time because each investigator was expected to improve with each subsequent run. Within each replication, the three methods were randomly assigned to each of the three investigators, who then conducted the methods in a random order. Two samples were included for each extraction. The mean values for these two samples were used in subsequent data analysis. Each investigator recorded the time needed to complete each method, and time required for manual steps such as pipetting and tissue homogenization.

Data were analyzed using the general linear model procedure of the Statistical Analysis System (SAS Institute, 1990) and main effect means were compared using orthogonal contrasts. For the model $[y=\mu+$ Replication + Investigator + Method + Investigator $x$ Method $+\varepsilon]$, replication was random, while all other effects were considered fixed. Model interaction terms that included Replication were nonsignificant $(P>0.25)$, so these terms were used as a pooled error estimate.

\section{Results}

Material costs for the three DNA extraction methods varied significantly (Table 1). Cost per sample (US\$) was \$3.04 for DNeasy ${ }^{\mathrm{TM}}$ kits, $\$ 0.99$ for the DNAzol ${ }^{\circledR}$ Reagent method, and $\$ 0.39$ for the PEX/CTAB extraction.

Extraction time differences attributable to Investigator or Method were both significant $(P=0.05)$ (Table 2). Furthermore, since the Investigator $\times$ Method interaction was significant for extraction time, the fastest Method was dependent upon the Investigator. Still, contrasts between Methods across all Investigators determined the DNAzol ${ }^{\circledR}$ method required significantly less time than either other method. The time required for DNeasy $^{\mathrm{TM}}$ and PEX/CTAB extraction were not significantly different even though the PEX/CTAB method did not have a tissue homogenization step.

The DNAzol ${ }^{\circledR}$ method extracted significantly more DNA when expressed on a

Table 1. Comparison of material costs per sample (US\$) for three DNA extraction methods. All costs are based on recent catalog pricing (Dec. 2000).

\begin{tabular}{|c|c|c|c|c|c|}
\hline \multicolumn{2}{|c|}{ DNeasy $^{\mathrm{TM}} \mathrm{Kit}^{\mathrm{z}}$} & \multicolumn{2}{|c|}{ DNAzol $^{\circledR}$ Reagent $^{y}$} & \multicolumn{2}{|c|}{ PEX/CTAB method ${ }^{\mathrm{x}}$} \\
\hline Item & Cost (\$) & Item & Cost $(\$)$ & Item & Cost $(\$)$ \\
\hline$\overline{\text { Kits (250) }}$ & 2.26 & Reagent & 0.52 & Buffer & $<0.002$ \\
\hline Solutions & NA & Chloroform & 0.02 & $\mathrm{Na}$ acetate & $<0.01$ \\
\hline Ethanol & 0.03 & Ethanol & 0.03 & Ethanol & 0.08 \\
\hline Buffers & NA & $1 \times \mathrm{TE}$ & $<0.01$ & $1 \times \mathrm{TE}$ & $<0.01$ \\
\hline Centrifuge tubes & 0.21 & Centrifuge tubes & 0.14 & Centrifuge tubes & 0.14 \\
\hline Pipet tips & 0.54 & Pipet tips & 0.29 & Pipet tips & 0.16 \\
\hline Total cost & 3.04 & & 0.99 & & 0.39 \\
\hline
\end{tabular}

${ }^{2}$ Qiagen, Valencia, Calif.

yGIBCO BRL, Rockville, Md. (formerly Life Technologies).

${ }^{x}$ Sigma-Aldrich, St. Louis, and Fisher Scientific, Pittsburgh.

${ }^{\mathrm{NA} N o t}$ applicable.

$\mathrm{gm} \cdot \mathrm{L}^{-1}$ basis $(P=0.001)$ than either the DNeasy ${ }^{\mathrm{TM}}$ or PEX/CTAB method (Table 2). But, since the final volume of the $\mathrm{DNeasy}^{\mathrm{TM}}$ and $\mathrm{DNAzol}^{\circledR}$ methods were 200 and $100 \mu \mathrm{L}$, respectively, the two methods had nearly the same total quantity of DNA extracted: $53.6 \mathrm{ng}$ for DNAzol ${ }^{\circledR} \mathrm{vs}$. $56.4 \mathrm{ng}$ for the more expensive DNeasy ${ }^{\mathrm{TM}}$ method. The PEX/CTAB method, which did not include a tissue homogenization step, extracted the least amount of DNA and had poor DNA banding patterns (Fig. 1).

The undergraduate investigator with 2 years of DNA extraction experience (\#2) was significantly faster than the graduate students. The more experienced graduate student (\#1) was also faster than the graduate student (\#3) who had the least DNA extraction experience. Because the Investigator $\times$ Method interaction was significant for extraction time $(P=0.01)$, the fastest Investigator was dependent upon which Method was being conducted. For the more experienced Investigators (\#1 and \#2), the DNAzol ${ }^{\circledR}$ method required the least amount of time. For Investigator \#3, the PEX/CTAB method required the least amount of time. The total DNA concentration in the final extract was $75 \%$ greater for Investigator \#3 with no experience $(P<0.017)$, while the total DNA extracted by both of the more experienced investigators did not differ significantly from one another.

Table 2. DNA concentration and extraction time for three methods and three investigators following DNA extraction from Kentucky bluegrass. Study was a full factorial arrangement in a randomized complete-block design blocked by replication. Within each replication, the three methods were randomly assigned to each of the three investigators who then conducted the methods in a random order. Two samples were included for each extraction.

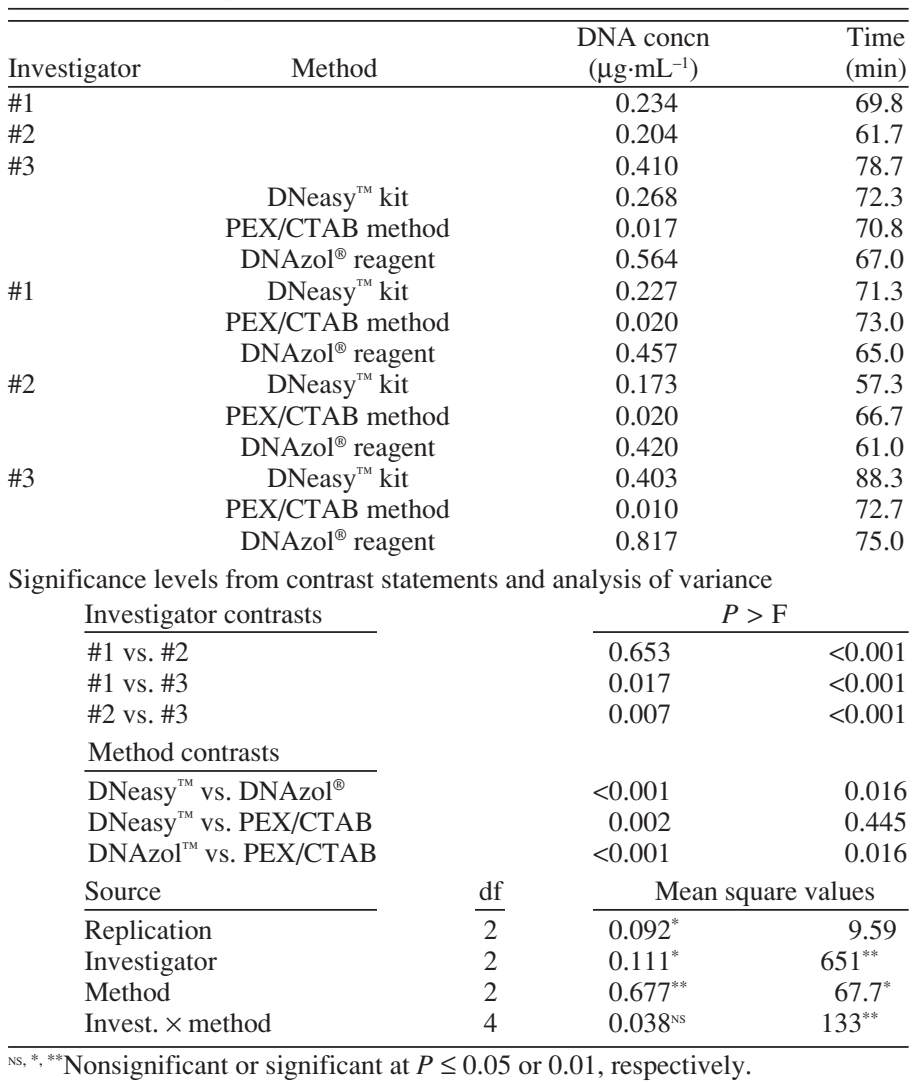


- DNeasy $^{\mathrm{TM}}$-- - PEX - - - DNAzol ${ }^{*}$ -

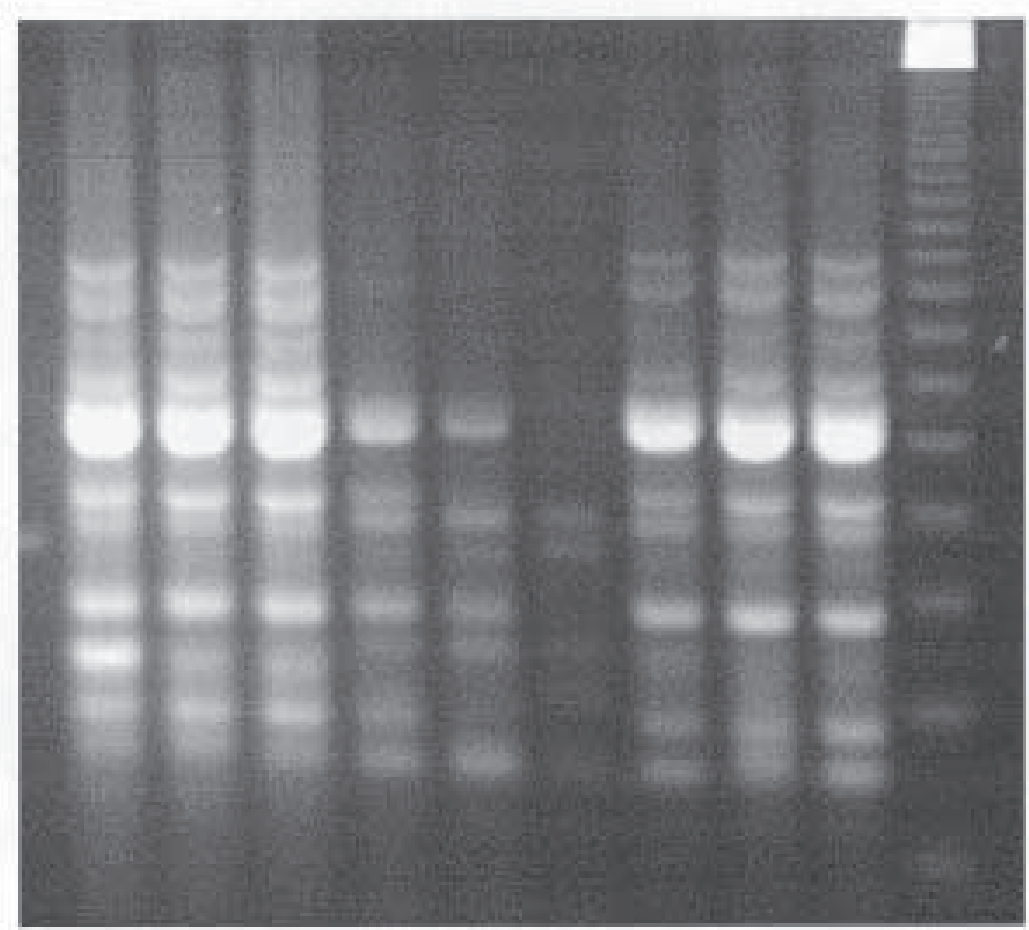

bp

1230

738

Fig. 1. RAPD banding patterns following isolation from 'Blacksburg' Kentucky bluegrass by DNeasy ${ }^{\mathrm{TM}}$ kits, DNAzol ${ }^{\circledR}$ reagent, or PEX/CTAB method. Each of the three replications for Investigator \#2 are shown. The far right lane is a 123 base pair ladder. Primer was OPA-10.

\section{Discussion}

If hundreds or thousands of plant samples are analyzed, the PEX/CTAB or DNAzol ${ }^{\circledR}$ methods are significantly more affordable, assuming these methods extracted adequate DNA for the intended use. Both the DNeasy ${ }^{\text {TM }}$ and DNAzol ${ }^{\oplus}$ methods required tissue homogenization by mortar and pestle in liquid $\mathrm{N}$. Laboratory equipment and liquid $\mathrm{N}$ costs were not quantified, but all extraction methods required the use of a microcentrifuge, vortex, and, with the exception of the DNAzol ${ }^{\circledR}$ method, a heated water bath. Furthermore, the costs associated with the PCR were not quantified in this study. Therefore, if a laboratory had to purchase equipment and supplies to conduct these procedures, the DNAzol ${ }^{\circledast}$ method might be most affordable. Still, the DNAzo $^{\circledR}$ or the DNeasy ${ }^{\mathrm{TM}}$ method should provide enough DNA for 26 PCR reactions ( $2 \mathrm{ng}$ each), while the DNAzol ${ }^{\oplus}$ method would cost $67 \%$ less for each unit of DNA extracted from the plant.

The DNeasy ${ }^{\mathrm{TM}}$ method required a significant amount of time for eluate transfers by pipette. Therefore, this method was more labor intensive with a greater chance of error due to contamination by foreign DNA or pipette errors. The fixed time required per sample for incubation, centrifugation, and drying ranged from $55 \mathrm{~min}$ for PEX/CTAB, $44 \mathrm{~min}$ for the DNAzol $^{\circledR}$ method, and 39 minutes for the DNeasy $^{\mathrm{TM}}$ method. If it is assumed that the remainder of the total time listed in Table 2 was used for tissue grinding, pipetting, and sample transfers, the PEX/CTAB and DNAzol ${ }^{\circledR}$ methods required much less time for manual operations. Both of these methods had more time available to conduct other laboratory tasks enhancing investigator efficiency.

The microcentrifuge used in this study could process 30 samples at one time. Therefore, if the time and costs associated with processing 30 samples are calculated, the effect of manual operations (i.e., pipetting, tissue grinding, etc.) should be considered. The PEX/CTAB method would be the fastest, requiring 8 h 49 min, while the DNAzol ${ }^{\circledR}$ and DNeasy $^{\mathrm{TM}}$ methods would require $12 \mathrm{~h} 14 \mathrm{~min}$ and $17 \mathrm{~h} 18 \mathrm{~min}$, respectively. This time element would cause significant differences in costs associated with laboratory labor. If laboratory labor is $\$ 6.00 / \mathrm{h}$, the total cost of materials and labor to process 30 samples would be $\$ 64.60$ for PEX/CTAB, $\$ 103.10$ for DNAzol ${ }^{\circledR}$, and $\$ 195.00$ for DNeasy ${ }^{\text {TM }}$. Likewise, extracting DNA from 1000 plant samples would require $576 \mathrm{~h}$ and $\$ 6500$ for DNeas $\mathrm{y}^{\mathrm{TT}} \mathrm{kits}, 407$ $\mathrm{h}$ and $\$ 3436$ for DNAzol ${ }^{\oplus}$ Reagent, and $294 \mathrm{~h}$ and \$2153 for the PEX/CTAB method.

The experienced Investigator (\#2) found the DNeasy ${ }^{\mathrm{TM}}$ Kit the fastest method, probably because this student had performed this method on over 480 plant samples within the previous year. Investigator \#2 had little experience with the DNAzol ${ }^{\circledR}$ or PEX/CTAB methods. Still, this student completed the DNAzol ${ }^{\circledR}$ method nearly as quickly as the DNeasy ${ }^{\text {TM }}$ method. Interestingly, the Investigator (\#3) with the least amount of DNA extraction experience extracted $75 \%$ more DNA than the two more experienced investigators. Therefore, none of the three methods required a significant amount of laboratory experience to complete successfully, and experience is inversely related with DNA yield.

The RAPD banding patterns for DNA extracted by the PEX/CTAB method were unsatisfactory (Fig. 1). This may be due to miniscule amounts of DNA available for PCR (Table 2), or inadequate purification, which did not eliminate polysaccharides or nucleases. If leaf samples had been homogenized prior to extraction, as conducted for the other two methods, the results might have been more satisfactory. The addition of a homogenization step would have added to the time required to conduct the PEX/CTAB extractions. Other laboratories indicate that success without tissue homogenization is highly dependent upon the plant species and the stage of development (Scott Warnke, Oregon State Univ., personal communication, 2000). Clearly, if the PEX/ CTAB method can be conducted in a reproducible and acceptable manner, cost savings could be tremendous when a large number of samples require processing.

The RAPD banding patterns for DNA extracted by either the DNeasy ${ }^{\mathrm{TM}}$ or DNAzol ${ }^{\circledR}$ method differed only slightly from one another (Fig. 1). Bands from the DNeasy ${ }^{\mathrm{TM}}$ method appeared more intense than bands from the DNAzol ${ }^{\circledR}$ method, probably as the result of varying DNA concentrations during the PCR or the presence of DNA-binding substances. Polymorphisms between closely related individuals may be more detectable using the DNeasy $^{\mathrm{TM}}$ Kit than the other methods, but practitioners should test all three methods on their species of interest before choosing a method. Conversely, if the goal is to identify an unknown plant by comparison with a known individual by DNA fingerprinting, the DNAzol ${ }^{\circledR}$ reagent would be satisfactory.

The DNAzol ${ }^{\circledR}$ reagent was a time- and cost-efficient method of DNA extraction from Kentucky bluegrass relative to the DNeasy ${ }^{\mathrm{TM}}$ kit. In studies where a thousand plant samples must be extracted, the DNAzol ${ }^{\circledR}$ reagent is a viable alternative that would save more than $\$ 3000$ and $170 \mathrm{~h}$ of labor. Conversely, if an investigator is extracting DNA from only 2550 plants with the objective of determining genetic diversity, conducting pedigree analysis, or to identify genes in closely related individuals, the DNeasy ${ }^{\mathrm{TM}}$ kit may be the best option for obtaining reproducible amplification products that are distinctly defined following gel electrophoresis. Both the DNAzol ${ }^{\circledR}$ and DNeasy ${ }^{\mathrm{TM}}$ methods purified enough DNA for 26 PCR reactions, while the PEX/CTAB method did not provide reproducible results. The slowest investigator, with the least DNA extraction experience, extracted $75 \%$ more DNA than the more experienced investigators when averaged over all three methods. Therefore, none of the three methods seem to require a significant amount of laboratory experience to complete successfully. Still, the results may have been different with a larger test 
population, rather than having conclusions based on the performance of one student.

\section{Literature Cited}

Doyle, J.J. and J.L. Doyle. 1990. Isolation of plant DNA from fresh tissue. BioTechniques 12:1315.

Gelfard, D.H. and T.J. White. 1990. Thermostable DNA polymerases, p. 129-141. In: M.A. Innis, D.H. Gelfard, J.J. Sninsky and T.J. White (eds.). PCR protocols: A guide to methods and applications. Academic Press, San Diego.

Geuna, F., H. Hartings, and A. Scienza. 2000. Plant DNA extraction based on grinding by reciprocal shaking of dried tissue. Anal Biochem. 278:228230.

Golembiewski, R.C., T.K. Danneberger and P.M Sweeney. 1997. Potential of RAPD markers for use in the identification of creeping bentgrass varieties. Crop Sci. 37:212-214.
Krebs, C.J. 1989. Ecological methodology . Harper \& Row, NY.

Lickfeldt, D.W. 2001. Kentucky bluegrass blend ecology. PhD Diss., Dept. of Natural Resources and Environ. Sci., Univ. of Illinois, Urbana.

Lin, J.J. and J. Kuo. 1998. A new reagent for simple isolation of plant genomic DNA. BioTechniques 20(2):46-48.

Lin, J.J., R. Fleming, J. Kuo, B.F. Matthews, and J.A. Saunders. 2000. Detection of plant genes using a rapid, nonorganic DNA purification method. BioTechniques 28(2):346-350.

Rogers, S.V. and A.J. Bendich. 1994. Extraction of total cellular DNA from plants, algae, and fungi. In: S.B. Gelvin and R.A. Schilperoort (eds.). Plant molecular biology manual. 2nd ed. Kluwer Academic, Dordrecht.

SAS Institute. 1990. SAS/STAT users guide: Statistics, Ver. 6, 4th ed. SAS Inst., Cary, N.C.

Saini, H.S., M. Shepherd, and R.J. Henry. 1999 Microwave extraction of total genomic DNA from barley grains for use in PCR. J. Inst. Brew. $105: 185-190$

Strózycki, P.M. and A.B. Legocki. 1995. An efficient method for genomic DNA isolation from plant tissues. Acta Biochim Pol. 42(3):329-332.

Sweeney,P.M. and T.K. Danneberger. 1995. RAPD characterization of Poа аппиа L. populations in golf course greens and fairways. Crop Sci. 35:1676-1680.

Weir, B.J., R.G. St. Pierre, and R.N. Chibbar. 1996. Isolation of DNA for RAPD analysis from leaves of the Saskatoon (Amelanchier alnifolia Nutt.) and other horticultural crops. Can. J. Plant Sci. 76:819-824.

Weising, K., H. Nybom, K. Wolff and W. Meyer. 1995. DNA fingerprinting in plants and fungi. CRC Press, Boca Raton, Fla.

Williams, C.E. and P.C. Ronald. 1994. PCR Template-DNA isolated quickly from monocot and dicot leaves without tissue homogenization. Nucleic Acids Res. 22:1917-1918. 